Original Research Paper

\title{
Why Southern Mediterranean Countries Fail To Innovate?
}

\author{
Trabelsi Ramzi \\ Researcher in the High School of Commerce, Manouba, Tunisia
}

Article history

Received: 20-04-2015

Revised: 01-06-2015

Accepted: 09-06-2015

E-mail: ramziramzi68@yahoo.fr

\begin{abstract}
This paper aims to analyze the factors that influence research investment in the Mediterranean region. We used a robust fixed effects model to analysis a panel of 22 countries for the period 2000-2012. The results showed that the FDI, the high technology export, the human capital devoted to research, intermediate and final production sectors, are significant and stimulate the Southern innovative capacity. The private R\&D is a substitution to public $R \& D$. The private returns exceed its social returns to R\&D since Southern governments don't invest too much like private firms in the innovative activities. The role of foreign institutions and international organizations is almost nonexistent in financing the southern research investments. The salaries don't motivate the researchers and Scientifics since it has a negative effect on the R\&D. The imports, the active population, the inflation, the technology infrastructure, the patent production have no effective contributions to the investment in the $R \& D$ in the Southern Mediterranean countries.
\end{abstract}

Keywords: Innovation Determinants, R\&D, Mediterranean Region, Panel

\section{Introduction}

The first economist who had highlighted the role of innovation and technological change as a growth engine was Schumpeter (1950). Countries which provide intensive resources for Research and Development (R\&D) will ensure certainly a high economic performance in the future. The activity of research and development give a clear picture about the degree of economic efficiency of a country. A country that gives more importance to $R \& D$ is classified among the nations that record the highest annual rate of economic growth. The determinants of $\mathrm{R} \& \mathrm{D}$ are a large debate between economists in the field of knowledge economy. According to the OCDE (2005) definition, the research and development are two activities that constitute the innovation process. The research activity serves for the production of completely new knowledge, while the development activity introduces a new or improved products or processes.

Since the 90s, developed countries have been engaged in the innovation race by devoting more spending on R\&D. The EU aims to reduce the gap with the United States, even the divergence between the EU Members in terms of growth rate, while the developing countries that are unable to manage their own R\&D; they still rely on the technology transfer from the Northern countries. Globally, the global research system is expanding. According to the World Bank (2012),
Finland, Sweden and Denmark are the most competitive Europeans countries in the research field with 3, 55\%, 3, $41 \%$ and $2,98 \%$ of its GDP devoted to R\&D. In the middle east area, Israel is the most advanced country in the research field as it devote huge resources about $3,93 \%$ of its GDP. In the American continent, The USA takes the lead with 2, 79\% of its GDP devoted to R\&D. In the Asian area, there are some super powers are rising in the international technological field. South Korea is the most innovative country in the world. It spent $4.4 \%$ of its GDP on R\&D in 2012 followed by Singapore and China, which provides respectively $2,1 \%$ and $1,98 \%$ of its GDP on R\&D. In the Southern Mediterranean region, Tunisia spent about $1,21 \%$ of its GDP on R\&D in 2009 (According to National Trends and International Comparisons of $\mathrm{R} \& \mathrm{D}$ spending included in the Science and Engineering Indicators (2012) report in chapter 4). The rest of countries didn't show a significant contribution of its domestic research investment in the economic growth. These countries are enabling to drive its own R\&D activities to reduce the technological gap with the UE that aim to rise its global spending on R\&D to $3 \%$ until 2020 (It figures between the 5 targets of the European commission until 2020: $3 \%$ of the EU's GDP (public and private combined) to be invested in $R \& D /$ innovation). 
In November 1995, The Barcelona Declaration has brought together the two interfaces of the Mediterranean. The cooperation in terms of $R \& D$ was one of the programs issued by the Barcelona Process, the European Neighborhood Policy and the Union for the Mediterranean. But, these programs didn't solve the weaknesses of the innovation capabilities in the southern countries. These countries have not yet recorded a significant increase in R\&D. Despite the cooperation with the EU, they still count on the technology transfer via European FDI, which is always a weak point for these countries' development plans. However, with the reinforcement of intellectual property rights as a primary condition to activate commercial agreements between countries. The technologies became more sophisticated and hard to imitate. The countries of the South Mediterranean must rely on their internal factors to improve their domestic innovation system. So, by comparing the South and the North we will attempt to identify the weaknesses of southern research activity. As Wang (2009) mentioned at the end of his research paper:

"A final caveat is that the results of this study were based on the sample of 26 OECD countries only. The validity of application to other economies, particular to developing economies, merits further investigation (Following the finding and the suggestion of Wang (2009), I included the developing countries which are in my case the southern Mediterranean countries in the scope)».

Section 2 reviews the theoretical and empirical literature. Section 3 discusses our empirical methodology, data and contains the main results. Section 4 will be dedicated to the conclusion.

\section{Literature Review}

The theories of economic growth focused on the endogenous technological change to explain the growth issue of world economies. Trade is a way to exchange technologies between countries. The technologies incorporated in the imported and exported products allow the transfer of knowledge's. Romer (1990), Grossman and Helpman (1991) affirmed that the commercial opening provides access to a global stock of knowledge. The open access to larger markets, promotes the exploitation of increasing returns to scale and avoid excessive activities in the sectors of research by devoting a larger share of human capital in R\&D.

Connolly (2003) showed that technology imports are more important for developing countries than developed countries, taking into account that it represents a shortcut to the modernization of the industrial sector.

Grossman and Helpman (1995), Coe et al. (1997), Keller (1998), Eaton and Kortum (2001; 2002) Dullek and Foster (2008) argued that the import is considered as a transmission channel of technology; it is the intermediate product that is exchanged between MNCs and their subsidiaries located abroad. Some countries have benefited from the use of the technology embodied in equipment and intermediate goods to push their innovation by imitation such as China. So, countries aiming to succeed in R\&D must increase the number and quality of the human capital such as Scientifics and engineers whom able to assimilate any kind sophisticated imported technology. In the same vein, Nelson and Phelps (1966) analyzed the relationship between education and growth through innovation. They concluded that the high quality of education stimulates the degree of innovation. It allows workers to acquire new knowledge's and produce more scientists and engineers. In the least developed countries, education facilitates the adaptability of the new technology and improves research productivity. According to Jones (1995), the knowledge growth rate is determined by the growth rate of the active population (number of researchers and engineers) and the importance of dynamic externalities such as the technological diffusion. If the growth rate of the population rise, the number of researchers and scientists and the knowledge stock also tends to increase, this stimulates more resources into R\&D activities.

The wage is a crucial factor to motivate local researchers and prevent their migration to developed countries. Although that Jones (1995) had criticized the contribution of Romer (1990), but they had agreed about many the importance of Wage as a research incentive. A wage subsidy to the human capital in the research sector will increase the share of labor devoted to R\&D.

A patent is the legal and official form of technological diffusion. It is regarded in the theory as an incentive to innovate in developed countries. But, it represents a protective force against imitation in the developing countries. As Barton (2004) said: "The strengthening of patent systems throughout the world appears likely to strengthen the position of incumbent multinationals and disfavor the independent development of technology by indigenous firms in developing nations" (Barton (2004). Trips and the global pharmaceutical market. Health affairs, vol. 23, $\left.n^{\circ} 3,146-154\right)$. Romer (1990) stated that the patent is an incentive to $R \& D$ and knowledge transfer. But, he preferred that the patent will not be only a protection tool. It must facilitate the production and the transfer of the knowledge. Römer argued in an interview that: "Because everybody can use the idea at the same time, there's no tragedy of the commons in the intellectual sphere. There's no problem of overuse or overgrazing or overfishing an idea" (See the interview of Bailey, Ronald, "Post-Scarcity Prophet: Economist Paul Romer on Growth, Technological Change and an Unlimited Human Future", Reason, December 2001).

A country with higher absorptive capabilities will benefit from the high technology export from developed 
nations. The absorptive capacity is a firm's ability to develop and improve its new products through the adaptation and application of the external technology stock [Cohen and Levinthal (1990)]. Greenaway and Yu (2004) show that learning-by exporting boost technology transfer and foster the innovation activity. Mansfield (1986) concluded that there is an increase in the rate of technology transfer between countries. Countries that invest more in R\&D assimilate faster the foreign technology so innovate easier.

The government and Private sector play an important role in fostering national innovation. Furman, Porter and Stern (2000) stated that Innovative capacity depends in part on the overall technological sophistication of an economy and its labor force, but also on an array of investments and policy choices by both government and the private sector. The public and private funding of R\&D must rise together to cover the high cost of innovative activity. To understand the nature of interaction between the public and private funding of R\&D, Guellec and de la Potterie (2001) studied the impact of public funding of R\&D on private $R \& D$ in the case of 16 countries OECD between 1980 and 1998. They found that the public funding of research positively influences the financing of private $R \& D$, with every dollar given to companies is equivalent to an average of 1.70 dollars for research. Damijan et al. (2006) and Liu and Buck (2007) show that domestic firms' R\&D activities are also important drivers of innovation. Porter and Stern (2000) are the first who studied the determinants of innovation of the OECD countries between 1973 and 1993. They found that innovation is positively linked to human capital in the R\&D sector and national knowledge stock. They stated the imported role of public policy that plays an important role in shaping a country's national innovative capacity. The government can increase the level of $R \& D$ resources and set up incentives to encourage human capital investment in the research sector. Goolsbee (1998) reviewed the American case. He argued that the majority of $R \& D$ funding is directed towards the payment of the high salaries of $R \& D$ personnel. This public funding of R\&D increases wages and not the effort in research. Thus, public funding gives more rewards to human capital and generates little innovation. If scientists' wages increase for firms that do not receive federal support for $\mathrm{R} \& \mathrm{D}$, the public financing has a crowding out effect on the private $R \& D$.

\section{Empirical Methodology}

\section{Model Specification and Variables}

In drawing on the work of Wang (2009) who analyzed the determinants of R\&D in OCDE countries in different contexts, we will add the southern Mediterranean countries and we will preserve some of OCDE countries in our final sample (The first sub-sample is called the Southern Mediterranean countries which include 6 MENA developing countries with 4 Eastern Europeans developing countries. The second sub-sample include 12 developed countries members of the Euro-zone and the OCDE, I called it the Northern Mediterranean countries. The next Table 1 contain all the countries included in our work.

The description of the variables is represented in the Table 3. The specification of the basic equation in its general form can be written as:

$R=\beta_{i} l+\beta_{m} M+\beta_{z} z+\mu$

where, $\mathrm{R}$ is the intensity of $\mathrm{R} \& \mathrm{D}$ investment of each country, $I$ is a set of variables always included in the regression, such as the labor force with tertiary and secondary education ratio and the proportion of researchers in total population, the active population and the inflation rates, $M$ is a vector of variables of primary interest, which includes the patent per capita ratio, technology transfer through import, export and FDI and $R \& D$ personnel salaries and $Z$ is a subset of variables chosen from a pool of macroeconomic variables that are considered to be potentially important explanatory variables in addition to the M-variable of primary variables such as R\&D funding sources (government, private sector and abroad) and financial sector quality.

\section{Estimation Procedure and Results}

Our model (1) is estimated using the conventional technique of static panel model; the fixed effects model (Within) and the method of random effects (Random), followed by the test of Hausman (1978). We will check whether the model is correct via the autocorrelation tests of residues, the endogeneity, the heteroscedasticity, the normality test residue and the multi collinearity.

The final output of the estimation is figured in the next Table 2 for both sub-samples.

Table 1. List of countries

\begin{tabular}{ll}
\hline Developed countries (North) & Developing countries (South) \\
\hline France & Tunisia \\
Belgium & Egypt \\
UK & Algeria \\
Finland & Morocco \\
Germany & Turkey \\
Spain & Jordanie \\
Portugal & Lituanie \\
Netherlands & Roumanie \\
Sweden & Bulgarie \\
Austria & Croitia \\
Denmark & \\
Slovakia & \\
\hline
\end{tabular}


Table 2. Estimation results

\begin{tabular}{|c|c|c|c|c|}
\hline & Southern Mediterran & & Northern Mediterran & \\
\hline & WITHIN ROBUST & MCG & WITHIN ROBUST & MCG \\
\hline & 0,928 & $0,000 * * *$ & $0,000 * * *$ & $0,005 * * *$ \\
\hline CONST & $(0,791)$ & $(1,069)$ & $(-25,376)$ & $(0,492)$ \\
\hline & 0,737 & $0,026^{* *}$ & $0,000 * * *$ & $0,003 * * *$ \\
\hline LPA & $(0,505)$ & $(0,727)$ & $(5,051)$ & $(0,914)$ \\
\hline & $0,022 * *$ & 0,824 & $0,075^{*}$ & $0,048 * *$ \\
\hline LWAGE & $(-0,323)$ & $(-0,072)$ & $(0,095)$ & $(1,117)$ \\
\hline LIM & $(0,222)$ & $(0,024)$ & $0,327)$ & $(0,750)$ \\
\hline & 0,239 & 0,947 & 0,292 & $0,037 * *$ \\
\hline LIDE & $(0,238)$ & $(0,127)$ & $(0,056)$ & $(0,046)$ \\
\hline & $0,007 * * *$ & 0,20 & $012 * *$ & 0,326 \\
\hline LINF & $(-0,025)$ & $(0,041)$ & $0,007)$ & $(-0,022)$ \\
\hline & 0,501 & 56100 & $0469 * *$ & 0,529 \\
\hline LBVP & $(0,175)$ & $(0,166)$ & $(0,152)$ & $(0,224)$ \\
\hline LXT & $\begin{array}{l}0,593 \\
0.401\end{array}$ & $\begin{array}{l}0,551 \\
0,385)\end{array}$ & $\begin{array}{l}0,551 \\
(-0,008)\end{array}$ & $\begin{array}{l}0,0137^{* *} \\
(-0,002)\end{array}$ \\
\hline & $0,024 * *$ & $0,002 * * *$ & $0,026^{* *}$ & 0,942 \\
\hline LEMPRD & $(0,949)$ & $(0,696)$ & $(0,629)$ & $(0,765)$ \\
\hline $\mathrm{IJ} \mathrm{B} \cap \mathrm{R} \mathrm{S} F \mathrm{C}$ & 0,9880 & $018 * *$ & $0,052 * *$ & $0,000 * * *$ \\
\hline LLBORSEC & $\begin{array}{c}(1,566) \\
0,291\end{array}$ & $\begin{array}{l}(0,971) \\
0,529\end{array}$ & $\begin{array}{l}(-0,69) \\
0,805\end{array}$ & $\begin{array}{l}(0,087) \\
0,878\end{array}$ \\
\hline LRDAB & $(-0,061)$ & $(0,054)$ & $(0,0005)$ & $(-0,001)$ \\
\hline & $0,044^{* *}$ & 0,437 & 0,824 & 0,318 \\
\hline LRDGOV & $\begin{array}{l}(0,066) \\
0,011 * *\end{array}$ & $\begin{array}{l}(0,418) \\
0,068^{*}\end{array}$ & $\begin{array}{l}(-0,783) \\
0,921\end{array}$ & $\begin{array}{l}(0,576) \\
0,528\end{array}$ \\
\hline LRDFIRM & $(-0,984)$ & $(-0,442)$ & $(-0,018)$ & $(0,476)$ \\
\hline & 0,119 & $0,026^{* *}$ & 0,674 & 0,496 \\
\hline LINFRA & $(-0,495)$ & $(-0,706)$ & $(-0,078)$ & $(-0,173)$ \\
\hline LLABORTER & $0,012 * *$ & 0,686 & $0,000 * * *$ & 0,351 \\
\hline LLABORTER & $\begin{array}{l}(1,0 /) \\
0,000 * * *\end{array}$ & $\begin{array}{l}(0,201) \\
0,054 *\end{array}$ & $0,064 *$ & $\begin{array}{l}(0,459) \\
0,89\end{array}$ \\
\hline FINFREE & $0,113)$ & $(0,08)$ & $(0,037)$ & $(0,005)$ \\
\hline
\end{tabular}

Note: In parenthesis are the coefficients of variables in $\log$ form. ${ }^{*}, * *$ And $* * *$ defines the $10 \%, 5 \%$ and $1 \%$ significance levels

Table 3. Variables definitions and sources

\begin{tabular}{|c|c|c|}
\hline Variables & Definitions & Sources \\
\hline LDRD2 & The log of expenditures on research and development expressed as the percentage of GDP & World Bank \\
\hline LPA & The log of the active population per million populations. it describes the log of employment in general & World Bank \\
\hline LWAGE & $\begin{array}{l}\text { The } R \& D \text { personnel remuneration as a percentage of } R \& D \text { expenditures. Goolsbee }(1998) \text { noted that } \\
\text { labor costs in research sector represent at least two thirds of } R \& D \text { expenditure and that this number } \\
\text { is relatively stable over time }\end{array}$ & Author \\
\hline LIM & $\begin{array}{l}\text { The logarithm of imports of goods and services as a percentage of GDP. it is the first technology transfer } \\
\text { channel between the two shores of the Mediterranean }\end{array}$ & WTO \\
\hline LIDE & $\begin{array}{l}\text { The logarithm of foreign direct investment inflows expressed in million current. This is the second } \\
\text { technology transfer channel in our analysis }\end{array}$ & WIPO \\
\hline LBVP & $\begin{array}{l}\text { Patent per capita ratio (number of total patents deposited by resident and non-residents divided on the } \\
\text { active population). it indicates the logarithm of the R\&D output or scientific, it allows researchers } \\
\text { and innovators to protect their inventions. }\end{array}$ & WIPO \\
\hline LXT & $\begin{array}{l}\text { The log of high-tech export as a percentage of manufactured goods. As a proxy positive externalities } \\
\text { or spillovers generated by foreign R\&D activity. }\end{array}$ & WTO \\
\hline LINFRA & $\begin{array}{l}\text { The log of import of ICT as a percentage of GDP. This variable describes the level of modernization } \\
\text { of the technological infrastructure of each country. }\end{array}$ & World Bank \\
\hline FINFREE & $\begin{array}{l}\text { The degree of financial freedom used as a proxy for the level of banking and financial developments. } \\
\text { If it equal } 1 \text { then there is financial freedom or financial and banking system is well developed, if it } \\
\text { is equal zero then there is a failure in the financial and banking system }\end{array}$ & Usherbrooke base \\
\hline LEMPRD & $\begin{array}{l}\text { The labor share that specializes in R\&D sector } L A L \text { (number of researchers on total workforce), this } \\
\text { variable indicates the use of high qualified human capital in R\&D called the technical employment. }\end{array}$ & Undata \\
\hline LLABORSEC & $\begin{array}{l}\text { The logarithm of the share of the labor force that has a secondary education compared to the } \\
\text { total workforce, it reflects the low-skilled labor out R\&D activity and which is attached to the final } \\
\text { goods sector that does not require a large stock of knowledge. }\end{array}$ & World Bank \\
\hline LLABORTER & $\begin{array}{l}\text { The logarithm of the share of the workforce with university education compared to the total } \\
\text { workforce, it reflect the qualified workforce in the intermediate goods sector, which requires a high } \\
\text { quality of human capital and high skills that can adapt to technological change. }\end{array}$ & World Bank \\
\hline LRDAB & The logarithm of the share of R\&D funding from abroad compared to the total expenditure on R\&D. & UNDATA \\
\hline LRDGOV & The logarithm of the share of public $R \& D$ funding compared to the total $R \& D$. & UNDATA \\
\hline LRDFIRM & The logarithm of the share of private $R \& D$ funding compared to total $R \& D$. & UNDATA \\
\hline LINF & The logarithm of inflation measured by the annual rate of growth of the implicit GDP deflator & IFM \\
\hline
\end{tabular}




\section{Results Analysis}

\section{Multi-Collinearity Test}

The multi-collinearity is checked by looking to the Variance Inflation Factor (VIF) which measures how the variance of the coefficients is inflated by the multicollinearity. The basic rule is that multi-collinearity is a problem if VIF is greater than or equal to 10 . The outcome in the Appendix shows that we have no multicollinearity problem because the VIF Mean $=5.33$ is less than 10 and the VIF of all variables is less than 10 and (1/VIF) exceeds $10 \%$.

\section{The Model Configuration: Pooled or Specific Effect?}

If the regression shows a p-value associated with the statistic Fisher less than $1 \%$ or $5 \%$, so the null hypothesis is rejected and the model is with effects. This effect may be fixed or random leading to perform the Hausman (1978) test.

Our result shows a p-value $=0.000$, which is below $5 \%$ critical value. So, the null hypothesis is not verified, which brings us to ensure that our model is characterized by a specific effect that can be fixed or variable. Therefore, we test the model in both cases; we use the Hausman test (1978) for discriminating between fixed or random effect of our model.

\section{Hausman (1978) Specification Test}

The first result of the Hausman test indicates a positive value prob $>$ chi $(2)=0.000$, but the test tells us that the variance-covariance matrix is not positive; this poses a problem for the quality of the Hausman test. So, to solve the problem, we perform the Hausman test with the addition of an option named Sigmamore. The addition of this option is preferable in the case of doubt about the positivity of the covariance matrix because it may be due to the reduced sample size. The test corrects the Hausman test sign and displays a prob $>$ chi (2) = $0.000<5 \%$, so we reject the null hypothesis indicating that our model is with fixed effect (Within).

\section{Autocorrelation, Heteroscedasticity and Normality Tests}

To solve the problem of autocorrelation AR(1), we use the command xtserial. The null hypothesis show that there is no autocorrelation of the first order, if prob $>F$ is less than $5 \%$ so the initial condition is not validated. The result in Appendix indicates that prob $>\mathrm{F}=0.0003$ is less than $5 \%$. So, there is an autocorrelation of order errors AR (1). To fix the autocorrelation of errors, we adopt the method of Generalized Least Squares (GLS) for a fixed effect model.
The Breusch-Pagan can be used to detect the heteroscedasticity. If the p-value is less than the significance level $(1 \%, 5 \%, 10 \%)$, then the null hypothesis of Homoscedasticity is canceled. The result gives a $\mathrm{p}$-value $=0.0459<10 \%$. So, there is a problem of heteroscedasticity.

To check if the residuals are normally distributed. The p-value must be upper 5\% so the null hypothesis will be accepted. According to the results shown in the Appendix, the p-value $=0.1420$ is greater than $5 \%$. Hence: the null hypothesis is validated and residues follow a normal distribution.

\section{Endogeneity Test}

We adopt the method of Hausman (OLS Vs. IV) which follows the following steps:

First, we estimate the instrumental variable model (ivreg) by making sure that there is no heteroscedasticity in the model (IV). Then we check the quality of our instruments using the Sargan test (overid). We record the previous procedure (eq1 is stored) and we estimate the model by OLS (reg). Finally, we adopt the Hausman test, if the probability test is greater than $10 \%$, so instruments are exogenous and there is no difference between the estimated model with Instrumental Variables (IV) and (OLS). This leads us to drop the method of double generalized least squares (2SLS two-stages least squares) and keep the OLS method.

Indeed, four variables are suspected of endogeneity because they well correlated with the dependent variable (LRD): the share of skilled labor in R\&D (LEMPRD), the patents per capita ratio (LBVP) and the two variables that define public and private funding of $R \& D$ (LRDGOV and LRDFIRM). We use the lagged variables lag (1) and lag (2) as instruments. In the Appendix, the result indicates that the instruments are valid since the Sargan test exceeds the threshold of $15 \%$ mentioned by Roodman (2006). Then, the Hausman test shows a prob $>$ chi (2) less than $10 \%$. So, the instruments are not endogenous. We can keep the initial OLS method and we are not obliged to use the method of two-stages least squares.

\section{Discussion}

In our analysis, we refer to the results gathered from the fixed effect robust model (Within estimator) that corrects heteroscedasticity.

In the North, the FDI coefficients are significant at the $5 \%$ threshold and positively affected the R\&D. For cons, the second technology transfer channel remains not significant since these countries are purely exporting technology to the South and East of the Mediterranean. The FDI is having the expected impact on the innovative activity of the southern countries. About 1\% increase in 
FDI flow lead to an increase of $0,23 \%$ in the $R \& D$ investment. But, the import is not significant. It does not seem the best way by which southern countries absorb the new technologies produced by the Northern countries. It is not significant and has no impact on domestic R\&D. So, the FDI is the main and unique way by which technology transfer takes place and imports do not encourage the domestic R\&D activities of southern countries due to the adaptation problems of the new technology, the enforcement of intellectual property rights, the lack of effective national policies and strategies for improvement of domestic R\&D activities.

The coefficient of the active population is significant and positive, so the employment level generally encourages more research in the North. Although, this factor is a very important attribute to the South, it has no effect on local R\&D. The Immigration of skilled labor force to the North and the high unemployment rate of graduates in the South are detrimental to their development. In addition, the quality of human capital stock is insufficient to ensure the success of R\&D projects, the quality and quantity of human capital stock is an essential element for the success of R\&D projects. On the other hand, the export of high technology in the South is significant and stimulates the innovation activity. The positive spillovers of foreign research activity transferred via the cooperation between the affiliates of multinationals corporations and local companies' benefits the host country. They provide new technologies, techniques and collaborations that enhance the performance of $R \& D$ and the adaptation of local researchers to new technologies. The non-significance of the production of patents in southern countries is sign that southern countries failed to innovate, knowing that the majority of patents belong to foreign residents. The rigidity of the intellectual property system and the high cost of patents application disable the ambitious young researchers.

The employment in the research, intermediate and final goods sectors represented by the number of researchers working full time, the workforce with a university and secondary level are significant and they impact research investments at the two sub-regions. In southern countries, the low-skilled labor affects the R\&D more than the high-skilled labor qualification; hence the demand for less skilled labor in favor of the final goods sector exceeds the demand for high-skilled labor devoted to the research and intermediate goods sectors. We note that the $\mathrm{R} \& \mathrm{D}$ sector is not a priority for southern countries, they specialize more in the intermediate and final production process since it is less costly and risky. Unlike, in the North, the less skilled labor is significant but inhibits the research activity. While, the coefficient of high-skilled labor remains significant and it stimulates R\&D. Thus, the salary of $R \& D$ personnel has a significant and a negative impact on $R \& D$ in the southern countries; an increase of one unit of salaries decrease the value of $R \& D$ investment by 0,32 units.
The research activity is very costly and the financial means are not sufficient. However, the local researchers do not receive sufficient rewards due to the mismanagement of funds and the lack of political will to enhance the status, the dynamics and the visibility of the local researchers.

On the other hand, the coefficient of the funding of $\mathrm{R} \& \mathrm{D}$ by private firms is not significant in the North. But, we stress the increased role of governments in financing the R\&D. A $1 \%$ increase in public funding of R\&D lead to a depreciation of $0.783 \%$ of expenditure on R\&D. This fact doesn't give a positive sign to the UE about achieving a level of annual expenditure on R\&D of $3 \%$ of GDP until 2020, considered that $2 / 3$ should be financed by the private sector. Much R\&D is performed and financed by the public sector in particular and the role of private firms is not perfect. Moreover, the role of international institutions in terms of providing financial incentives to research activities in the southern countries is totally absent.

In the southern Mediterranean countries, the R\&D funds are provided by the private sector which is a substitute of public and foreign funding. The private research is not considered as a high quality research because it's devoted basically to the development and innovation tasks. The fundamental research is totally absent. In other hand, we notice that the coefficient of financial and banking sector development level is significant and contribute positively in the innovation activity in the two sub-regions. The inflation rate and the technology infrastructure are insignificant, so they don't contribute to the innovation activity in southern countries.

\section{Conclusion}

This paper attempt to investigate the causes behind the failure of innovation activity in the Southern Mediterranean countries. In drawing on the work of Wang (2009) and Birdsall and Rhee (1993), I used a set of 22 Mediterranean countries between 2000 and 2012. Our results are based on the fixed effect robust model. We compared between the North as a reference and the South of Mediterranean sub-regions.

The results showed that the FDI, the high technology export, the human capital devoted to research, intermediate and final production sectors, are all significant and stimulate the Southern innovative capacity. The low-skilled labor affects the R\&D more than the high-skilled labor and the human capital of research sector. So, the final production sector is more competitive than the intermediate and the research sectors. The failure of southern Mediterranean countries lies in the absence of government role in the implementation and financing the internal research activity. The salaries don't motivate the researchers and Scientifics efforts since it has a negative effect on R\&D. 
The share of private R\&D funding is significant but inhibits the R\&D. Every supplement unit invested by private sector lead to a loss of 0,9 units in the total expenditures of R\&D. The structure of the labor market in northern Mediterranean countries tends towards the high-skilled labor force more specifically in the research and intermediate sector. However, the low-skilled labor dominates the labor market structure in southern Mediterranean countries. The private funding of $R \& D$ is the main source in southern countries. But, it has a negative impact on the research efforts since the public initiative is negligible, so the private return to $R \& D$ is greater than the social return to $R \& D$.

The imports, the active population, the inflation, the technology infrastructure, the patent production have no effective contribution to the investment in $R \& D$. The share of R\&D funding from abroad is non-significant and don't have an effect on the research investments. The role of foreign institutions and international organizations are almost nonexistent in financing the southern research investment. This is a handicap especially for southern countries that really need to diversify their financial resources to mobilize their innovation activities.

The local R\&D efforts are ineffective in southern countries. This is due to the lack of initiative of the state, the disconnection between the industry and the university and the mismanagement of financial resources. This confirms the hypothesis that foreign technology can be considered as a substitute for domestic R\&D in developing countries. However, the national SMEs do not have the necessary tools to be involved in some technological cooperation, given the fragility of the destruction-creation process that accelerate the substitution of obsolete technologies by new ones. This is due to the problems to adapt smoothly to technological changes and the lack of fiscal incentives and subsidies for R\&D.

The evolution of the population is a very crucial factor that promotes R\&D according to Jones (1995). A greater percentage of the population in a country that has received higher education implies that the country is more concerned about the accumulation of knowledge and scientific exploration. But, the poor quality of the education system, the institutions and the research centers, the low number of researchers and salaries engaged in full time are very modest in southern Mediterranean countries.

Finally, I suggest that southern Mediterranean governments must focus on some tasks in future: They must improve the educational systems by rising up funds toward the fundamental academic research. Facilitate the transition from university to the industry. Invest more in the research infrastructure. Decentralize the system of innovation. Encourage companies to establish long-term effective partnerships with public universities.

\section{Acknowledgment}

I would like to thank Professor Akri ben Saleh and Professor Ghazi Boulila for their valuable and helpful suggestions.

\section{Funding Information}

The authors are the only source of funding for this paper.

\section{Author's Contributions}

Ramzi Trabelsi Designed the framework and objectives of the research. Designed research methodology. Formulated the study model. Prepared and writing the literature review. Estimated the models, analyzed and interpreted the results and revised the paper.

\section{Ethics}

This article is original and contains unpublished material. The corresponding author confirms that there are no ethical issues involved.

\section{References}

Barton, H.J., 2004. Trips and the global pharmaceutical market. Health Affairs, 23: 146-154.

DOI: $10.1377 /$ hlthaff.23.3.146

Birdsall, N. and C. Rhee, 1993. Does research and development contribute to economic growth in developing countries? Working paper No 1221, Policy Research, The World Bank, Washington, DC.

Coe, D.T., E. Helpman and A.W. Hoffmaister, 1997. North-south R\&D spillovers. Econ. J., 107: 134-149.

Cohen, W.M. and D.A. Levinthal, 1990. Absorptive capacity: A new perspective on learning and innovation. Administrative Sci. Q., 35: 128-152. DOI: $10.2307 / 2393553$

Connolly, M., 2003. The dual nature of trade: Measuring its impact on imitation and growth. J. Develop. Econ., 72: 31-55. DOI: $10.1016 / \mathrm{S} 0304-3878(03) 00067-1$

Damijan, J.P., A. Jaklic and M. Rojec, 2006. Do external knowledge spillovers induce firms' innovations? Evidence from Slovenia. LICOS Discussion Paper 156/2006, University of Ljubljana.

Eaton, J. and S. Kortum, 2001. Technology, trade and growth: A unified framework. Eur. Econ. Rev., 45: 742-755. DOI: 10.1016/S0014-2921(01)00129-5

Eaton, J. and S. Kortum, 2002. Technology, geography and trade. Econometrica, 70: 1741-1779.

DOI: $10.1111 / 1468-0262.00352$ 
Hausman, 1978. Specification test in econometrics. Econometrica, 46: 1251-1271.

Goolsbee, A., 1998. Does government R\&D policy mainly benefit scientists and engineers? National Bureau of Economic Research WPS No. 6532, Cambridge, MA.

Greenaway, D. and Z. Yu, 2004. Firm-level interactions between exporting and productivity: IndustrySpecific Evidence. Rev. World Econ., 140: 376-392. DOI: $10.1007 / \mathrm{BF} 02665981$

Grossman, G. and E. Helpman, 1995. Technology and Trade. In: Handbook of International Economics, Grossman, G.M. and K. Rogoff (Eds.), Elsevier, New York, ISBN-10: 9780444815477, pp: 1279-1337

Guellec, D. and B.V.P. de la Potterie, 2001. R\&D and productivity growth: Panel data analysis of 16 OECD countries. OECD Economic Studies No. 33.

Jones, C.I., 1995. R\&D-based models of economic growth. J. Political Econ., 103: 759-784.

Keller, W., 1998. Are international R\&D spillovers trade-related? Analyzing spillovers among randomly matched trade partners. Eur. Econ. Rev., 42: 1469-1481. DOI: $10.1016 / \mathrm{S} 0014-2921(97) 00092-5$

Liu, X. and T. Buck, 2007. Innovation performance and channels for international technology spillovers: Evidence from Chinese high-tech industries. Res. Policy, 36: 355-366.

DOI: $10.1016 /$ j.respol.2006.12.003
Mansfield, E., 1986. Patents and Innovation: An empirical study. Manage. Sci., 32: 173-181.

DOI: $10.1287 / \mathrm{mnsc} .32 .2 .173$

Nelson, R.R. and E.S. Phelps, 1966. Investment in humans, technological diffusion and economic growth. Am. Econ. Rev., 56: 69-75.

OCDE, 2005. Oslo Manual: Guidelines for Collecting and Interpreting Innovation Data, 3rd Edn., Paris: OCDE.

Porter, M.E. and S. Stern, 2000. Measuring the 'Ideas' production function: Evidence from international patent output. Mimeo, MIT Sloan School of Management.

Roodman, D., 2006. How To Do xtabond2: An Introduction to "Difference" and "System" GMM in Stata, Center for Global Development Working Paper No. 103.

Romer, P.M., 1990. Endogenous technological change. J. Political Econ., 98: S71-S102.

Wang, E.C., 2009. Determinants of R\&D investment: The extreme-bounds-analysis approach applied to 26 OECD countries. Res. Policy, 39: 103-116. DOI: 10.1016/j.respol.2009.11.010 